\title{
THE SOCIAL ASPECTS OF THE DECENTRALIZATION PROCESS OF THE ADMINISTRATION IN THE REPUBLIC OF TURKEY
}

\author{
Hasan Azis \\ Assis. Prof. Ph.D. Burgas Free University, Burgas, Bulgaria, \\ hasan.azis@gmail.com
}

\begin{abstract}
In the present research the social aspects and the perspectives for development of the administration and the process of decentralization in the Republic of Turkey are analyzed. The transformation of the territorialstate structure through the social conditions and factors of the Turkish community and identity is considered. The article publishes the results of an analysis of the transformation of the territorial structure of the Republic of Turkey under the influence of some important socio-cultural factors.

The present study aims to establish the attitude of the state and municipal administration and their assessment to the decentralisation process in the Republic of Turkey. A questionnaire has been prepared, which included issues related to the rating of the decentralisation in the Republic of Turkey and the attitudes of the administration towards the integration process itself. A survey of the administration's competences and attitudes on decentralisation has been carried out. Recommendations have been given regarding the degree of completion of decentralization and development of the qualifications of the state and municipal administration. 224 employees participated in the study. The results outlined difficulties in the decentralisation process, as well as proposed ways to overcome them.
\end{abstract}

Keywords: Social aspects, socio-cultural factors, local government, central government, decentralisation, local self-government, administration, attitudes, competences.

\section{INTRODUCTION}

Much of the research unites around the statement that significant socio-economic benefits are being observed for societies and countries that have carried out successful steps towards reforms aimed at successfully integrating a decentralisation process. An example of a positive effect of properly implementing a decentralised governance process is that the communication between meeting the real consumer needs of the local government and providing the necessary budgetary funding for them is substantially improved (Georgiev, 2008a). This study proposes a methodology that can conduct a successful process assessment of the quality of work of the administration in a particular (mixed) region of the country in the conditions of the achieved level of decentralization in the Republic of Turkey. In order to take into account decentralisation in a comprehensive manner, the study analyzes the results of a survey of the opinion of the administration itself on decentralisation levels, its quality through the communication level between citizens and administrators, as well as the perspectives and necessary measures, related to the skills of the administration in this process.

\section{RATIONALE OF THE STUDY - MOTIVATION, FACTORS, METHODOLOGY}

The conduct of this study is provoked by several specific motivating factors, from which the following can be indicated: Firstly, despite the large amount of literary scientific sources on the topic of the impact of decentralisation on the scale of the state, its growth and macroeconomic stability, only a few of the studies have pointed out in their analyses how they assess the effects of decentralisation on the quality of service provision. Secondly, an approach is needed to present a more focused and detailed analysis on a particular 
manifestation of the functioning of the administration in the settings of the specific parameters of decentralisation (Kuranov, Deliev, Penev, 2000). Thirdly, the vast majority of research on this topic assessed the effects of decentralisation regarding the end results of public services. This means that the dependent variables used until now mainly include characteristics such as mortality, completion of education, student achievements, etc. But as long as you have the end results as dependent variables, they may be the results of demographic, social and political factors. The situation raises the need for an approach to analysing the relationship between decentralisation and provision of services in a different way. This study examines intermediate results (e.g. assessment of development level) or possessed qualities rather than end results of services as dependent variables. Fourthly, this study is also motivated by the ability to focus on variables that are only sometimes part of the analysis of this relationship in the literature. Most of the studies have typical variables such as the country's socio-economic characteristics in their empirical models (such as revenue, growth, demographic aspects, etc.). However, they don't get into aspects of discussion management that can improve service delivery. In short, this research deals with key aspects that are often overlooked in the literature on decentralisation, as a way to deepen our understanding of the implications of this reform as key to public development (Buzov, 1992; Bankova, 2014; Petkova - Georgieva, 2018).

\section{RESEARCH FOCUSED ON THE PROCESS OF INTEGRATION OF A DECENTRALSED FORM OF GOVERNANCE}

The problems related to decentralisation, central and local government and the need for their detailed analysis, research and creation of working models for their solution in practice are grounds for the development of this study. The ability to successfully define the characteristics and achievements of decentralisation in three different types of countries - in a candidate member - Turkey, member - Bulgaria and long-standing member - Greece becomes a key necessity for different types of structures and participants in this process. As well as to achieve the strategic goal of EU membership - cohesion. The data exported from the study are part of a large cross-border survey in three municipalities of Edirne, Kardzhali and Komotini.

The development of the decentralisation process based on the principles of the European charter of local self-government in Turkey creates prerequisites for a sustainable evolution of administrative capacity at different levels of government and self-government (Kanev, 2006; Petrova, Petrov, 2020).

224 respondents from the Republic of Turkey took part in the survey, of which 131 men and 89 women, of which 208 people work in the local/municipal administration, 11 are from the region/district administration and one person is from central/state administration, and four respondents did not respond to this question (Tables 1 to 4 and Plot 1 ).

Table 1. Distribution of the sample by sex and age

\begin{tabular}{|c|c|c|c|c|}
\hline & \multicolumn{2}{|c|}{ Sex } & \multirow[t]{2}{*}{ Total } \\
\hline & & Male & Female & \\
\hline \multirow{5}{*}{ Your age group is: } & From 18 to 29 years old & 7 & 4 & 11 \\
\hline & From 30 to 39 years old & 37 & 25 & 62 \\
\hline & From 40 to 49 years old & 30 & 26 & 56 \\
\hline & From 50 to 59 years old & 37 & 27 & 64 \\
\hline & 60 years and older & 20 & 6 & 26 \\
\hline \multicolumn{2}{|l|}{ Total } & 131 & 88 & 219 \\
\hline
\end{tabular}


Table 2. Distribution of the sample by sex and edication

\begin{tabular}{|c|l|c|c|c|}
\hline \multicolumn{2}{|c|}{} & \multicolumn{2}{c|}{ Sex } & \multirow{2}{*}{ Total } \\
\cline { 2 - 5 } \multicolumn{2}{|c|}{} & Male & Female & \\
\hline \multirow{3}{*}{$\begin{array}{c}\text { The highest degree } \\
\text { completed education is: }\end{array}$} & Basic & 5 & 1 & 6 \\
\cline { 2 - 5 } & Secondary & 41 & 5 & 46 \\
\cline { 2 - 5 } & Secondary special & 23 & 14 & 37 \\
\cline { 2 - 5 } & Higher, Bachelor & 25 & 29 & 54 \\
\cline { 2 - 5 } & $\begin{array}{l}\text { Higher, Master and } \\
\text { Higher }\end{array}$ & 35 & 40 & 75 \\
\hline \multirow{2}{*}{ Total } & & 129 & 89 & 218 \\
\hline
\end{tabular}

Table 3. Distribution of the sample by sex and job position

\begin{tabular}{|c|l|c|c|c|}
\hline \multicolumn{2}{|c|}{} & \multicolumn{2}{c|}{ Sex } & \multirow{2}{*}{ Total } \\
\cline { 2 - 4 } \multicolumn{2}{|c|}{} & Male & Female & \\
\hline \multirow{2}{*}{$\begin{array}{l}\text { In your work you have the } \\
\text { following job position: }\end{array}$} & Managerial & 75 & 30 & 104 \\
\cline { 2 - 5 } & Expert & 30 & 40 & 70 \\
\cline { 2 - 5 } & Technical & 20 & 16 & 36 \\
\hline \multicolumn{2}{|c|}{ Total } & 124 & 86 & 210 \\
\hline
\end{tabular}

Table 4. Service contacts between administration and citizens.

How often in your daily work do you have the opportunity to communicate and make contact with citizens?

\begin{tabular}{|c|c|c|c|c|}
\hline & Frequency & Percentage & $\begin{array}{l}\text { Valid } \\
\text { percentage }\end{array}$ & $\begin{array}{l}\text { Cumulative } \\
\text { percentage }\end{array}$ \\
\hline \multirow{2}{*}{$\begin{array}{l}\text { Every day } \\
\text { Rather often }\end{array}$} & 180 & 80.4 & 80.7 & 80.7 \\
\hline & 17 & 7.6 & 7.6 & 88.3 \\
\hline \multirow{3}{*}{$\begin{array}{l}\text { Rather rarely } \\
\text { Never } \\
\text { Total }\end{array}$} & 25 & 11.2 & 11.2 & 99.6 \\
\hline & 1 & .4 & .4 & 100.0 \\
\hline & 223 & 99.6 & 100.0 & \\
\hline Not responded & 1 & .4 & & \\
\hline Total & 224 & 100.0 & & \\
\hline
\end{tabular}




\section{Chart 1. Service relations between administration and citizens}

How often during your daily work you have the opportunity to communicate and make contact with citizens?

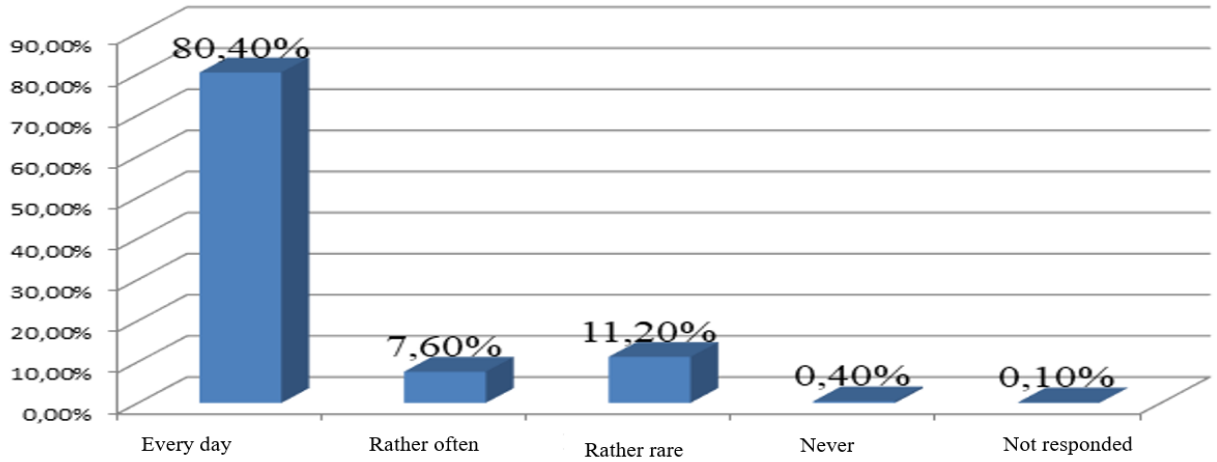

The figures depicted on the chart show that $88 \%$ of employees every day or rather often communicate with citizens and only one person has never had contact with citizens.

Table 5. Quality of services provided

If you had to put a overall rating of the quality of the services provided by the administration in which you work, what would it be?

\begin{tabular}{|c|c|c|c|c|}
\hline & Frequency & Percentage & $\begin{array}{l}\text { Valid } \\
\text { percentage }\end{array}$ & $\begin{array}{l}\text { Cumulative } \\
\text { percentage }\end{array}$ \\
\hline \multirow{2}{*}{$\begin{array}{l}\text { Very high } \\
\text { Rather high }\end{array}$} & 47 & 21.0 & 21.1 & 21.1 \\
\hline & 107 & 47.8 & 48.0 & 69.1 \\
\hline \multirow{2}{*}{$\begin{array}{l}\text { Neither high nor low } \\
\text { Rather low }\end{array}$} & 63 & 28.1 & 28.3 & 97.3 \\
\hline & 4 & 1.8 & 1.8 & 99.1 \\
\hline Very low & 2 & .9 & .9 & 100.0 \\
\hline Total & 223 & 99.6 & 100.0 & \\
\hline Not responded & 1 & .4 & & \\
\hline Total & 224 & 100.0 & & \\
\hline
\end{tabular}

\section{Chart 2. Quality of services provided}

If you need to give an overall rating to the quality of the services, provided by the administration where you work, what would it be?

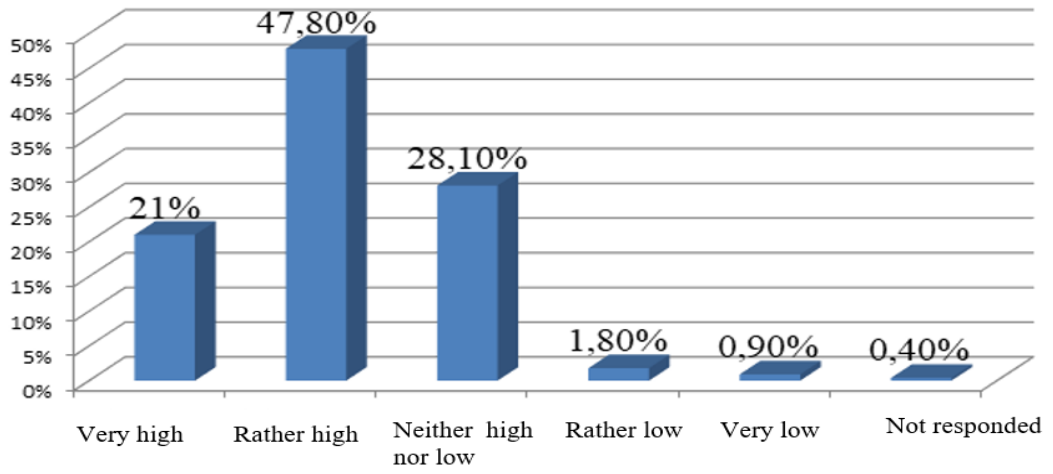

The majority of survey participants $-68.8 \%$, believe that they provide citizens with a very high or rather high 
quality of services.

Table 6. Evaluation of interaction between different authorities

\begin{tabular}{|l|l|l|l|l|}
\hline \multicolumn{5}{|c|}{$\begin{array}{l}\text { What overall rating would you put on the interaction process between the different } \\
\text { authorities in recent years? }\end{array}$} \\
\hline \multirow{2}{*}{} & Frequency & $\begin{array}{l}\text { Percenta } \\
\text { ge }\end{array}$ & $\begin{array}{l}\text { Valid } \\
\text { percentage }\end{array}$ & $\begin{array}{l}\text { Cumulative } \\
\text { percentage }\end{array}$ \\
\hline $\begin{array}{l}\text { Very high } \\
\text { Rather high } \\
\text { Neither high nor low } \\
\text { Rather low } \\
\text { Very low }\end{array}$ & 11 & 4.9 & 4.9 & 4.9 \\
\cline { 2 - 5 } Total & 53 & 23.7 & 23.8 & 28.7 \\
\cline { 2 - 5 } & 108 & 48.2 & 48.4 & 77.1 \\
\cline { 2 - 5 } & 40 & 17.9 & 17.9 & 95.1 \\
\cline { 2 - 5 } Not responded & 11 & 4.9 & 4.9 & 100.0 \\
\cline { 2 - 6 } & 223 & 99.6 & 100.0 & \\
\hline Total & 1 & .4 & & \\
\hline
\end{tabular}

Chart 3. Evaluation of interaction between different authorities

What would be your overall rating to process of interaction between the different authorities during the in the past years?

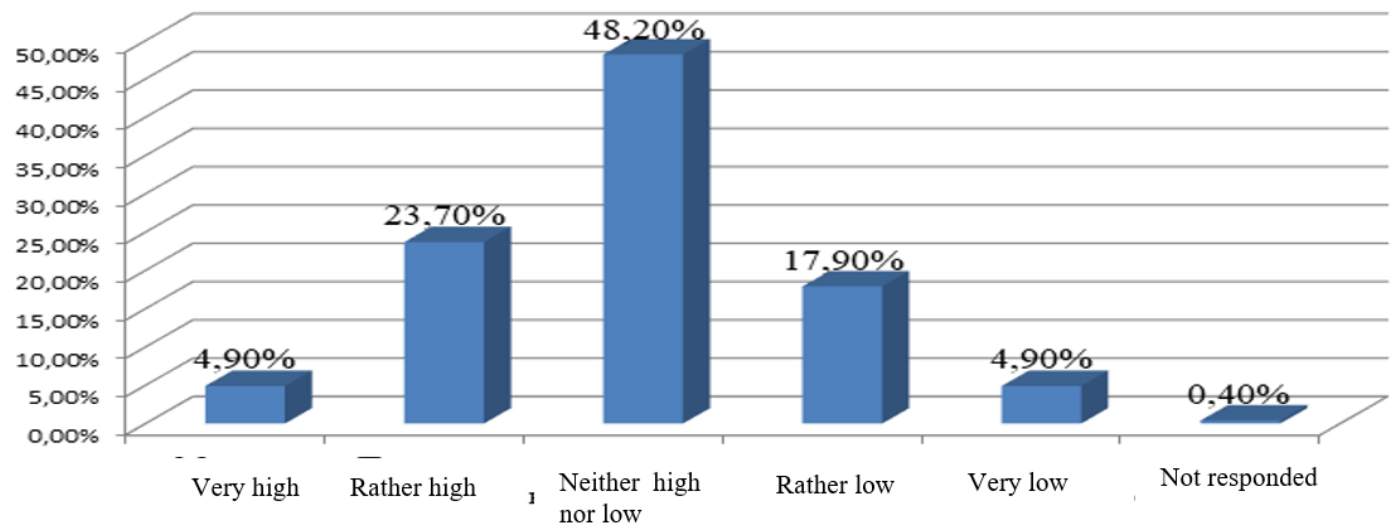

Table 7. Overall rating of the Decentralisation process

\begin{tabular}{|l|l|l|l|l|}
\hline \multicolumn{5}{|c|}{ If you had to put an overall rating of the decentralisation process, what would it be? } \\
\hline & Frequency & $\begin{array}{l}\text { Percenta } \\
\text { ge }\end{array}$ & $\begin{array}{l}\text { Valid } \\
\text { percentage }\end{array}$ & $\begin{array}{l}\text { Cumulative } \\
\text { percentage }\end{array}$ \\
\hline $\begin{array}{l}\text { Very high } \\
\text { Rather high }\end{array}$ & 4 & 1.8 & 1.8 & 1.8 \\
\cline { 2 - 6 } $\begin{array}{l}\text { Neither high nor low } \\
\text { Rather low } \\
\text { Very low } \\
\text { Total }\end{array}$ & 38 & 17.0 & 17.1 & 18.9 \\
\hline Not responded & 110 & 49.1 & 49.5 & 68.5 \\
\hline Total & 56 & 25.0 & 25.2 & 93.7 \\
\hline
\end{tabular}




\section{Chart 4. Overall rating of the Decentralisation process}

\section{What would be your overall rating to process of decentralisation?}

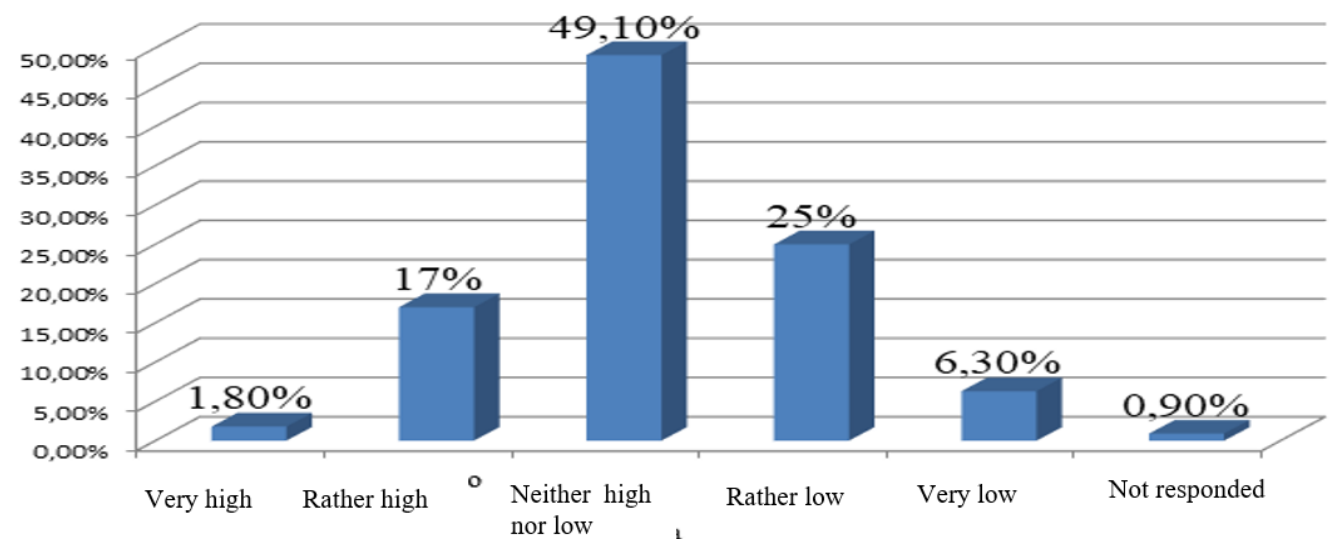

It is noteworthy that almost half of the persons participated in the survey $(49.10 \%)$ gave a neutral assessment of the decentralisation process. There is an imbalance to negative estimates $-1.80 \%$ have given a very high rating, against $6.30 \%$ with a very low one. For $17 \%$, the decentralisation process is rather highly rated, but for $25 \%$ this process is rather low rated (Tables 5 to 7 and Charts 2 to 4 ).

By conducting a t-test comparison of independent samples, the assumption of differences between men and women with regard to the assessment of the decentralisation process has been verified.

Table 8. Importance of the difference between men and women in the assessment of the decentralisation process

\begin{tabular}{|l|l|l|l|l|l|l|}
\hline & Sex & N & Mean & SD & t & P \\
\hline $\begin{array}{l}\text { If you had to put an overall rating of the } \\
\text { decentralisation process, what would it be? }\end{array}$ & Male & 131 & 3.19 & .954 & & \\
\cline { 2 - 9 } & Female & 88 & 3.15 & .687 & 0.38 & 0.69 \\
\hline
\end{tabular}

It follows from the data of the t-test that between men and women there is no significant difference in the assessment of the decentralisation process. The mean values in both men and women are close to the middle of the scale, meaning the rating is generally "neither high nor low." It can be argued that the result obtained is a confirmation of the objectivity of the assessment of the decentralisation process (Table 8).

With the application of a one-way analysis of variance has been verified the existence of a relationship between age and the overall rating of the decentralisation process (Bankova, Dimitrov, 2012; Petkova, 2008b). From the application of Leven's sample equality test, it was found that there was a significant difference between the number of individuals from different age ranges and therefore the group of individuals (11 persons only) aged between 18 and 29 years was excluded from the analysis.

Table 9. Dependence of overall assessment of decentralisation on the age

\begin{tabular}{|l|l|l|l|l|l|}
\hline & $\mathrm{N}$ & Mean & SD & $\mathrm{F}$ & $\mathrm{P}$ \\
\cline { 2 - 6 } & & & & & \\
\hline From 30 to 39 years old & 61 & 3.13 & .903 & & \\
\hline From 40 to 49 years old & 57 & 3.26 & .768 & & \\
\hline From 50 to 59 years old & 64 & 3.14 & .732 & 0.5 & 0.68 \\
\hline 60 years and older & 26 & 3.31 & .970 & & \\
\hline Total & 208 & 3.19 & .823 & & \\
\hline
\end{tabular}

The result obtained showed that there were no significant differences between the age groups and there was no dependence of the overall assessment of the decentralisation process on the age (Table 9). 
When the youngest study participants, aged between 18 and 29 years, were included in the analysis, the result of the analysis was again insignificant $(F=0.85, p=0.49, M=2.82, S D=1.32)$. From the data it follows that, as in the Bulgarian sample, the youngest give the highest rating of the decentralization process (Tables 10 to 11$)$.

Of all the individuals who took part in the study, only six were of primary education and therefore excluded this group from the one-way analysis of variance, which verified the existence of a relationship between age and the overall assessment of decentralisation.

Table 10

\begin{tabular}{|l|l|l|l|l|l|}
\hline & N & Mean & SD & F & p \\
\cline { 3 - 6 } & & & & & \\
\hline Secondary & 47 & 3.09 & .905 & & \\
\hline Secondary special & 37 & 3.27 & .804 & & \\
\hline Higher, Bachelor & 53 & 3.15 & .928 & 0.42 & 0.73 \\
\hline Higher, Master and Higher & 75 & 3.23 & .781 & & \\
\hline Total & 212 & 3.18 & .848 & & \\
\hline
\end{tabular}

It follows from the result obtained that the overall assessment of decentralisation does not depend on age.

Table 11

\begin{tabular}{|l|l|l|l|l|l|}
\hline & $\mathrm{N}$ & Mean & Std. Deviation & $\mathrm{F}$ & $\mathrm{p}$ \\
\hline Managerial & 105 & 3.23 & .835 & & \\
\hline Expert & 69 & 3.19 & .791 & 1.3 & 0.27 \\
\hline Technical & 36 & 2.97 & .878 & & \\
\hline Total & 210 & 3.17 & .830 & & \\
\hline
\end{tabular}

The overall assessment of decentralisation is not dependent and is not determined by the job position held. One of the factors that determine the success of the decentralisation process is its completion. Data from the percentage distribution on this question are shown in Table 12 and Chart 5

Table 12. Percentage distribution of the question of the completion of the decentralisation process

\begin{tabular}{|l|l|l|l|l|}
\hline \multicolumn{5}{|c|}{ In view of your personal experience, to what extent do you think this process has } \\
been completed?
\end{tabular}




\section{Chart 5 Completion of the decentralisation process}

According to your personal experience to what extent this process has been completed?

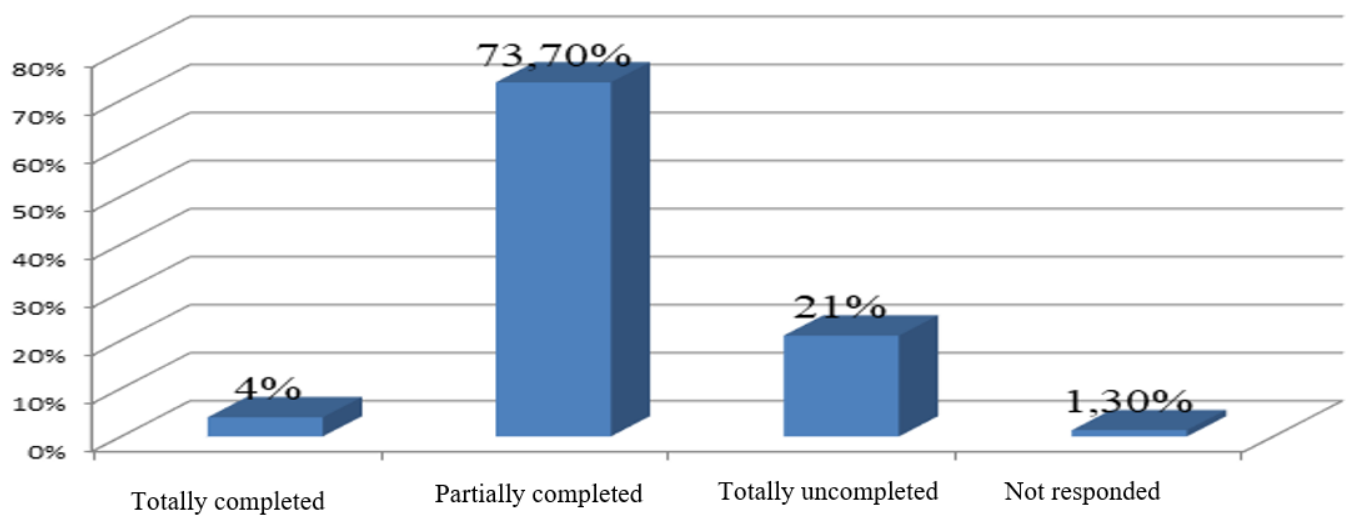

The prevailing opinion is that the decentralisation process is only completed to a certain stage. It is noteworthy that those who believe that the decentralisation process is incomplete are five times more than those who say decentralisation is a completed process (Petkova, Tasheva, Petkov, 2010).

In order to verify the role of the completion of the decentralisation process, a linear regression analysis was conducted as a predictor of the decentralisation process (Table 13).

Table 13

\begin{tabular}{|c|c|c|c|c|c|}
\hline \multirow[t]{2}{*}{$R^{2}=13.3 \%$} & \multicolumn{2}{|c|}{ Non-standardised ratios } & \multirow{2}{*}{$\begin{array}{l}\text { Standardised ratios } \\
\text { Beta }\end{array}$} & \multirow[t]{2}{*}{$\mathrm{t}$} & \multirow[t]{2}{*}{ Sig. } \\
\hline & $\mathrm{B}$ & Std. Error & & & \\
\hline $\begin{array}{l}\text { Predictor } \\
\text { In view of your personal experience, }\end{array}$ & 1.747 & .252 & & $\begin{array}{l}6.93 \\
9\end{array}$ & .000 \\
\hline $\begin{array}{l}\text { to what extent do you think this } \\
\text { process has been completed? }\end{array}$ & .656 & .113 & .365 & $\begin{array}{l}5.79 \\
5\end{array}$ & .000 \\
\hline
\end{tabular}

The completion of the decentralisation process is moderately strong, and is a positive prerequisite for the overall assessment of the decentralisation process and sets it at $13.3 \%$. On this basis, a prediction can be made that the more the decentralization process gets its completion, the higher the assessment for it is. After it was established that the completion of the decentralisation process was a factor in the assessment of decentralisation, the question arose to what extent the power of this factor varied depending on the position held. The results showed that the completion of the decentralisation process has the greatest suggestive force and is of greatest importance for individuals in technical positions, determining $16.1 \%$ of the overall decentralisation estimate $(\beta=0.4, p=0.01)$. For those in expert position, the completion of the decentralisation process has almost the same meaning and determines $15.6 \%$ of the overall decentralisation estimate $(\beta=0.39, p=0.01)$. The overall assessment of decentralisation is to the least extent determined by the completion of the decentralisation process $-7.7 \%$ for those in expert position $(\beta=0.27, p=0.004)$.

\section{FEATURES OF THE DECENTRALISATION PROCESS IN TURKEY}

The next group of questions concerns the assessment of characteristics that represent different aspects of the decentralisation process. Twelve statements were included in the scale, which were assessed by study participants on a five-step scale, where 1 was "Totally Agreed" and 5 was "Totally disagreed." The calculation of averages found that in the study participants from the Republic of Turkey, the highest rated characteristics were those relating to local government:

"There are conditions for local development policy" $(M=2.26, S D=0.99)$, "There are conditions for the local government to develop its capacity and potential" $(M=2.34, S D=1.07)$ "There is a flexible and effective model of local government in Bulgaria" $(M=2.47, S D=1.06)$. By applying the t-test paired comparison it was 
established that the existence of conditions for local development policy was statistically significantly higher appreciated than the existence of a flexible and effective local self-government model $(t=4,48, p=0)$ and marginally higher than the conditions which favour the local government to develop its capacity and potential $(t=1,92, p=0,055)$. Quality service for citizens is the other meaningful feature of the decentralisation process, which also has a high rating $(M=2.44, S D=1.03)$.

\section{Chart 6. The highest-rated statements from the scale to assess different aspects of decentralisation}

To what extent would you agree or disagree with the following statements related to the process of decentralisation in the country in the past years?

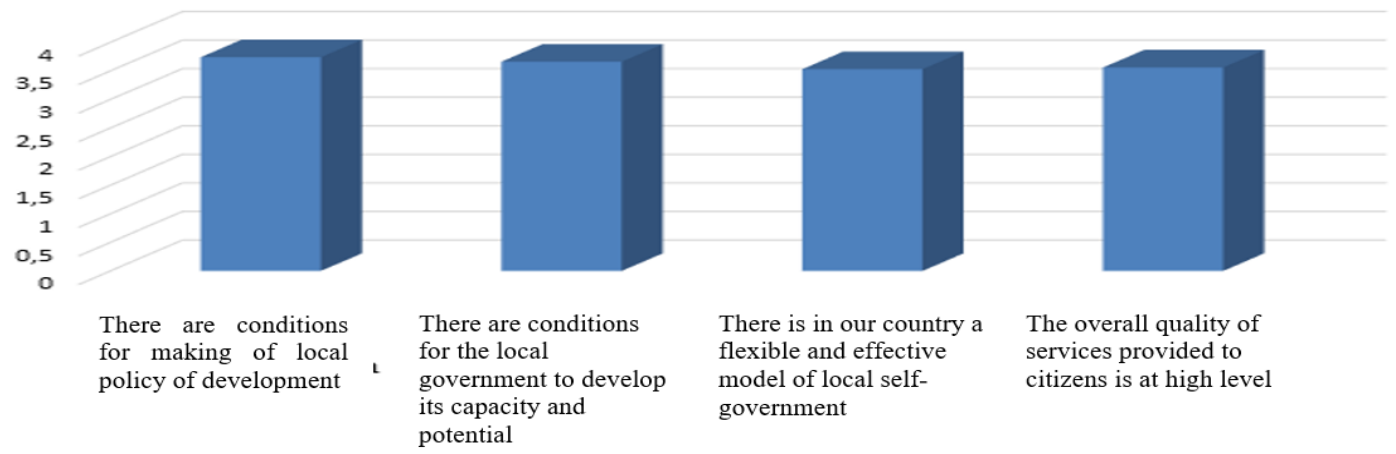

Note: For a clearer presentation of the results, the scale for assessment of the statements has been reversed, thus higher values also mean a higher estimate. The chart is made on the basis of averages.

The characteristics of local government, in turn, have a moderate and strong degree of dependence on the successful implementation of the European Charter for Local Self-Government, with the highest correlation with the existence of a flexible and effective model of local self-government $(r=0.63 ; p=0)$. Then follows the correlation with the availability of conditions for local policy and development $(r=0.43 ; p=0)$ and the conditions that support the local government to develop its capacity and potential $(r=0.37 ; p=0)$.

\section{RESULTS AND CONCLUSIONS}

The lowest-rated statements from this scale are:

"There is an enhanced dialogue and partnership between central and local authorities" $(M=3,08, S D=1,23)$;

"There are working laws to support the decentralisation process" ( $M=2,94, S D=1,05)$;

"The work of local, regional and national authorities is public and transparent for citizens" $(M=2.80$, $\mathrm{SD}=1.15)$.

The overall rating of all variables from the group of statements that relate to the characteristics of the decentralisation process is 2.61, a value that in the assessment scale lies between "I Somewhat Agree" and "I Neither Agree nor Disagree."

Despite some limitations of the present study as the use of a specifically adapted method, a representative group of employees from the state and municipal administration in Edirne, the results obtained in no case can be undervalued. In general, we can summarize that the decentralisation process is incomplete, important reforms in the transfer of resources from central to local government have not been implemented. Another feature of the decentralisation process is that it takes place unevenly and it is implemented with different success in different sectors.

Decentralisation should not be seen solely as a process of transferring powers, responsibilities and resources from central government to a lower hierarchical levels of country government. To a large extent, it is a process that is being deployed simultaneously on different management levels, and perhaps one of the most important for ensuring sustainability and transparency in the governance of local communities is ensuring the kind of local governance that includes participation of local communities in making and implementing local public policies.

\section{CONCLUSION}

Strengthening the administrative capacity, considered reasonably by the European Union as a key element of Turkey's development and by a higher level of satisfaction of its population with public structures, makes 
us generally give preference to an improvement in the existing organization.

The study allows for giving some recommendations in the work of state and municipal administration:

- To conduct more training and qualification courses, to stimulate state and municipal administration to achieve better personal competencies.

- To increase the capacity and responsibility of local authorities to formulate and implement municipal policies;

- To increase the capacity and responsibility of the regional administration to implement policy and ensure compliance between national and local interests.

- To increase the efficiency of allocating resources and powers based on equal dialogue between central and local authorities.

In parallel with the above, it should be taken into account that the current study is part of a larger research that tries to give a clear assessment of the decentralisation process in Bulgaria, Greece and Turkey through the view of the state and municipal administration. The main objective is also focusing on problems in solving specific policies, as well as planning activities to implement the recommendations for better governance. This will support the process of implementation of the Decentralisation Strategy in the new period 2016-2025, based on the analyses of previous periods and, as a result, fulfilling the previously unachieved objectives

\section{REFERENCE LIST}

Buzov, N., (1992). Local Government and Budgetary Autonomy of Municipalities, Luren, Sofia, 1992

Georgiev, L., (2008a). Decentralisation - understood and made in Journal of Public Administration, book 2, Sofia, 2008

Kanev, D., (2006). Management and Communications in Politics, Friedrich Elbert Foundation, Sofia, 2006

Kuranov, C., Deliev, I., Penev, P., (2000). Problems of decentralisation in local government in the Republic of Bulgaria, Friedrich Elbert Foundation, Sofia, 2002 FLGR, Local Government and Young People, or why participate in local government, FLGR, Sofia, 1998 FLGR, Building Vision and Strategic Community planning, FLGM, Sofia, 2000 Stanev, H., Y. Spiridonova, A. Dzildzhov, Decentralisation and its impact on the opportunities of municipalities and districts for absorption of funds from the European Union.

Bankova, I. T., Dimitrov, S., (2012). Characteristics and some problems of Afghanistan's public administration. Tribal agreements - an alternative supporting establishment of modern public administration, The 20th NISPAcee Annual Conference 'Public Administration East and West: Twenty Years of Development', May 23 - 26, 2012, Ohrid, Republic of Macedonia (FYR Macedonia)", ISBN 978-80-89013-63-0

Bankova, I. (2014). Administrative Conflicts in Bulgarian Regional Development Policy - Current, Situation, Trends, Possible Solutions. Regionalisation and Regional Policy in Central and Eastern Europe. Book Selectet Riversed Papers from the 21st NISPAcee Annual Conference 'Public Administration Of The Future', 16-18 May 2013. Belgrade, Serbia. 2014. ISBN 978-80-89013-73-9. p.305-317.

Petkova - Georgieva, S., (2018). Basic Problems to Solve in Strategic Controlling Implementation. // annual of University "prof. dr. Assen Zlatarov", Burgas, 2018, pp. 71 - 77, v. XLVII (2), ISSN 2603-3976

Petkova, S., Tasheva, Y., Petkov, P. (2010). Classification and possibilities of management of primary energy sources. // Oxidation Communications, 2010, 33 (2), pp. 462 - 469, ISSN 0209-4541

Petkova, S. (2008b). Balanced scorecard as instrument of strategic controlling. // Forum Gesundheit und Soziales, Beitrage aus Lehre, Forschung und Praxis der Studiengange der Evangelischen Fachhochschule, Berlin, 2008, Heft 6, pp. 60 - 68, ISSN 1863-1851

Petrova Teodora, Petrov Zhivo, (2020). Alternative Approaches for Long-Term Defence Planning, Proceedings of SOCIOINT 2020-7th International Conference on Advances in Education and Social Sciences, 20-22 January, 2020-Dubai, U.A.E., pp. 818-825, ISBN 978-605-82433-8-5 